\title{
NPIPB8 Gene
}

National Cancer Institute

\section{Source}

National Cancer Institute. NPIPB8 Gene. NCI Thesaurus. Code C140038.

This gene may be involved in the function of nuclear pores. 